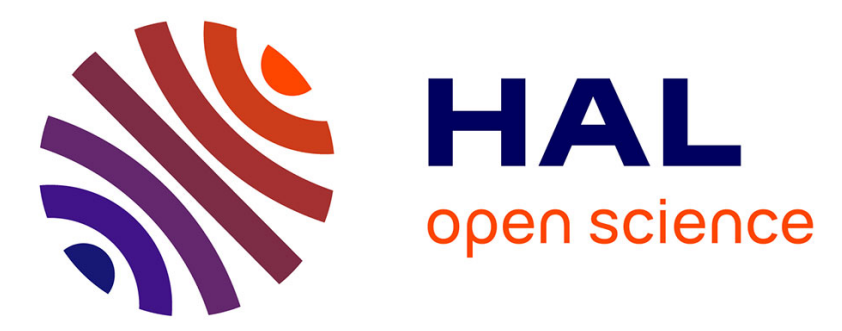

\title{
Indirect effects of experimental warming on dissolved organic carbon content in subsurface peat
}

Frédéric Delarue, Sébastien Gogo, Alexandre Buttler, Luca Bragazza, Vincent E.J. Jassey, Grégory Bernard, Fatima Laggoun-Défarge

\section{To cite this version:}

Frédéric Delarue, Sébastien Gogo, Alexandre Buttler, Luca Bragazza, Vincent E.J. Jassey, et al.. Indirect effects of experimental warming on dissolved organic carbon content in subsurface peat. Journal of Soils and Sediments, 2014, 14, pp.1800-1805. 10.1007/s11368-014-0945-x . insu-01056747

\section{HAL Id: insu-01056747 https://hal-insu.archives-ouvertes.fr/insu-01056747}

Submitted on 25 Aug 2014

HAL is a multi-disciplinary open access archive for the deposit and dissemination of scientific research documents, whether they are published or not. The documents may come from teaching and research institutions in France or abroad, or from public or private research centers.
L'archive ouverte pluridisciplinaire HAL, est destinée au dépôt et à la diffusion de documents scientifiques de niveau recherche, publiés ou non, émanant des établissements d'enseignement et de recherche français ou étrangers, des laboratoires publics ou privés. 


\section{Abstract}

Several studies on the impact of climate warming have indicated that peat decomposition/mineralization will be enhanced. Most of these studies dealt with the impact of experimental warming during summer when prevalent abiotic conditions are favorable to decomposition. Here, we investigated the effect of an experimental air warming by open-top chambers (OTCs) on water-extractable organic matter (WEOM), microbial biomasses and enzymatic activities taken from two contrasted moisture sites named Bog and Fen sites, the latter considered as the wetter ones. While no or few changes in peat temperature and water content appeared under the overall effect of OTCs, we observed that air warming smoothed water content differences and led to a decrease of mean peat temperature at the warmed Bog sites. Such a thermal discrepancy between the two sites led to a change of microbial structure and activities in opposite directions: a rise of hydrolytic activities at the warmed Bog sites whereas bacterial biomass was relatively enhanced at the warmed Fen sites. Such features were not associated with any change of WEOM properties namely carbon and sugar contents and aromaticity suggesting that air warming did not trigger any shift of OM decomposition. Indeed, using various tools, we underlined that the use of single indicators of OM decomposition can lead to fallacious conclusions. Finally, such patterns are able to change seasonally as a consequence of complex interactions between groundwater level and air warming suggesting the need to improve our knowledge using a high time-resolution approach. 
Experimental warming differentially affects microbial structure and activity in two contrasted moisture sites in a Sphagnum-dominated peatland

Frédéric Delarue ${ }^{1,2,3^{*}}$, Alexandre Buttler ${ }^{4,5,6}$, Luca Bragazza ${ }^{5,6,7}$, Laurent Grasset ${ }^{8}$, Vincent E.J. Jassey ${ }^{5,6}$, Sébastien Gogo ${ }^{1,2,3}$, Fatima Laggoun-Défarge $e^{1,2,3}$

${ }^{1}$ Université d'Orléans, ISTO, UMR 7327, 45071 Orléans, France

${ }^{2}$ CNRS, ISTO, UMR 7327, 45071 Orléans, France

${ }^{3}$ BRGM, ISTO, UMR 7327, BP 36009, 45060 Orléans, France

${ }^{4}$ Laboratoire de Chrono-Environnement, UMR CNRS 6249, UFR des Sciences et Techniques, 16 route de Gray, Université de Franche-Comté, F-25030 Besançon, France

${ }^{5}$ École Polytechnique Fédérale de Lausanne (EPFL), School of Architecture, Civil and Environmental Engineering (ENAC), Laboratory of Ecological Systems (ECOS), Bâtiment GR, Station 2, CH-1015 Lausanne, Switzerland

${ }^{6}$ WSL Swiss Federal Institute for Forest, Snow and Landscape Research, Site Lausanne, Station 2, Case postale 96, CH-1015 Lausanne, Switzerland

${ }^{7}$ University of Ferrara, Department of Life Science and Biotechnology, Corso Ercole I d'Este 32, I-44121 Ferrara, Italy

${ }^{8}$ CNRS, Laboratoire de Synthèse et de Réactivité des Substances Naturelles-UMR 6514, Université de Poitiers, 4 rue M. Brunet, 86022, Poitiers Cedex, France

*Corresponding author: Tel.: +331407948 43

E-mail: fdelarue@mnhn.fr 
Present address: Laboratoire de Minéralogie et de Cosmochimie du Muséum, UMR 7202 CNRS, Muséum National d'Histoire Naturelle, 57 rue Cuvier, 75231 Paris Cedex 05, France

\section{Introduction}

The impact of climate change and its consequence on global air temperature are still debated as some uncertainties remain (IPCC, 2007; Otto et al., 2013), in particular about the potential feedback of terrestrial carbon cycle to climate warming (Davidson and Janssens, 2006; Friedlingstein et al., 2006). In such a context, understanding the fate of the carbon stored in peatlands is crucial since these ecosystems contain about one-third of the world's soil organic carbon as peat (Gorham, 1991), the equivalent of about $60 \%$ of atmospheric carbon.

The carbon sink function of peatlands is mainly the result of waterlogged and anoxic conditions, low temperature and water acidity that reduce the microbial decomposition and promote the accumulation of organic matter $(\mathrm{OM})$ as peat. As a result, peat organic carbon is expected to be particularly sensitive to warming because of the higher intrinsic temperature sensitivity of this type of organic soil (Davidson and Janssens, 2006). Thus, a $1^{\circ} \mathrm{C}$ increase in air temperature has been estimated to enhance carbon fluxes from heterotrophic respiration in northern peatlands by about 38-100 Mt of carbon per year (Dorrepaal et al., 2009). Other works indicated that climate change can further diminish carbon sequestration by promoting growth of vascular plant which, in turn, depress the productivity of peat mosses (Breeuwer et al., 2009; Bragazza et al., 2013). In contrast to these studies, Loisel et al. (2013) and Charman et al. (2013) indicated that the carbon accumulation rate of many northern peatlands could increase in response to a warmer climate in the future, as long as moisture is not a limiting factor. These examples illustrate the ongoing debate on the fate of carbon in peatlands in response to climate change. Several works demonstrated the complex interaction between 
peat moisture and air temperature in regulating peat decomposition (Delarue et al., 2011b; Jassey et al., 2011; Bokhorst et al., 2013). Indeed, the need for investigating the impact of air warming on both peat temperature and peat moisture has been stressed formerly (Aerts et al., 2006; Aronson and Mcnulty, 2009), but few studies based on warming experiments have specifically addressed this topic, yet the close relationship between moisture, temperature and carbon cycling makes it a critical issue for peat decomposition (McNeil and Waddington, 2003). It was demonstrated that an increased water evaporation in peat soils and a drying out of their surface layer can decrease the soil's thermal conductivity which, in turn, can prevent heat to propagate deeper into the soil and therefore keep them colder (Dabros and Fyles, 2010). Other authors also reported that evaporation was associated to a cooling of the upper moss layers, inducing a condensation of vapor (Carleton and Dunham, 2003).

The peculiar environmental conditions in peatlands favor the establishment of Sphagnum mosses, which are known to produce recalcitrant litter enriched in polyphenolic compounds (van Breemen, 1995). Although polyphenols inhibit extracellular enzymatic activity (Freeman et al., 2001; Freeman et al., 2004), the enzymes belonging to the phenoloxidase group (PO) have the ability to degrade recalcitrant polyphenols accumulating in peatlands (McLatchey and Reddy, 1998; Freeman et al., 2001). In a perspective of climate change, PO activity is expected to increase as a consequence of more frequent drought events and associated oxygenation of peat soils (Fenner and Freeman, 2011). Due to a decrease of soluble phenols with increasing activity of PO, hydrolytic enzymes such as leucine amino-peptidase (LAP), $\beta$ glucosidase (BG) and acidic phosphatase (AP) are no longer inhibited so that the breakdown of OM can start. Following such cascading effects, various studies suggested that peat OM decomposition will be enhanced by climate warming (Dorrepaal et al., 2009; Fenner and Freeman, 2011; Jassey et al., 2013). However, such studies were mainly conducted during the summer months, when environmental constraints, i.e. water level drawdown and air 
temperature, were less limiting for microbial metabolism. Therefore, two major questions remain to be clarified: (1) how air temperature and water level interact to affect both soil temperature and moisture under conditions of water saturated peat and (2) how this interaction can affect the soil carbon cycle.

In this study we investigate the interactive effects of air warming, which was experimentally induced by Open-Top chambers (OTCs), and water level by comparing two habitats characterized by contrasted soil moisture conditions. The study was performed early summer when both soil water level and air temperature had not yet reached, respectively, their annual minimum and maximum values. Specifically, we explored peat moisture changes as a function of water level, air and peat temperatures. The impact of air warming and peat moisture on the soil carbon cycle was assessed using phospholipids fatty acids as an index of microbial biomass, various enzymatic activities (LAP, BG, PA and PO) as indexes of microorganism activities and the corresponding quality of water-extractable OM (WEOM).

\section{Material and Methods}

\subsection{Study site, experimental design and sampling}

The study site is an undisturbed ombrotrophic Sphagnum-dominated peatland situated in the Jura Mountains (Le Forbonnet, France; 4649'35'N, 6¹0’20”E), at an altitude of ca. $840 \mathrm{~m}$ a.s.1. The annual mean temperature at the site is ca. $6.5^{\circ} \mathrm{C}$, and the annual precipitation is about $1200 \mathrm{~mm}$ (Delarue et al., 2011a). Cold winters (mean monthly temperature ca. $1.4{ }^{\circ} \mathrm{C}$ ) and mild summers (ca. $14.6^{\circ} \mathrm{C}$ ) characterize the climate.

Peat samples were collected in late June 2011 across a vegetation gradient corresponding to a narrow transitional Fen-Bog area. The transition from the poor Fen to the Bog was characterized by a transition from an area of relatively flat and homogeneous surface 
dominated by Sphagnum. fallax with a low abundance of vascular plants (i.e. Eriophorum vaginatum, Vaccinum oxycoccus and Andromeda polifolia) to a surface with a patterned vegetation of hummocks, where S. magellanicum, V. oxycoccus, E. vaginatum and Calluna vulgaris developed, and hollows mainly occupied by S. fallax, Carex rostrata and A. polifolia. The main change between the poor Fen and the Bog sites was the occurrence of $S$. magellanicum in the Bog site, entailing a change in the microtopography (considered as a site effect).

The experimental design was described in detail in previous works (Delarue et al., 2011b; Jassey et al., 2011). Briefly, OTCs are passive warming chambers designed following the International Tundra Experiment (ITEX) to obtain quasi-natural transmittance of visible wavelengths and to minimize the transmittance of re-radiated infrared wavelengths (Marion et al., 1997; Aronson and McNulty, 2009). Six plots were equipped with OTCs in May 2008, whereas 6 other plots were used as controls (CTLs). For this study, the plots were named as follows: Bog-OTC and Bog-CTL for plots in the Bog site with and without OTCs respectively, and Fen-OTC and Fen-CTL for plots in the Fen site with and without OTCs respectively.

Temperature of peat $(7 \mathrm{~cm}$ deep) and air $(10 \mathrm{~cm}$ above Sphagnum capitulum) was automatically measured every 30 minutes using thermocouple probes in each plot and a data logger (CR-1000 Campbell). Monthly mean, minimum and maximum temperatures, for both peat and air, were then calculated for the period from January 2011 to June 2011. The ground water level was automatically measured in one randomly selected plot at both Bog and Fen sites (mid-May 2011 to late June 2011). Finally, peat moisture and temperature were measured at ca. $5 \mathrm{~cm}$ depth by Decagon ${ }^{\circledR}$ sensors only during the growing season (from early May 2011 to October 2011) in two randomly selected plots at both the Bog and Fen sites. Twelve peat cores $30 \mathrm{~cm}$ long were sampled in June 2011, after 3 years of experimental 
warming. The peat cores were cut into five slices ( 0 to 5,5 to 10,10 to 15,15 to 20 and 20-25 cm interval depth) and frozen. Within two weeks after sampling, each slice was subdivided in two parts. For each part, water was gently extracted following the procedure described by Delarue et al. (2011b) modified by the use of a PTFE filter $(0.45 \mu \mathrm{m}$ pore size $)$. Because of the potential solubilization of OM during water extraction, we preferred to define the analyzed water as WEOM rather than as pore water, even if most of the water may come from pore water in our procedure. After WEOM extraction, peat samples were dried at $105^{\circ} \mathrm{C}$ during 24 hours in order to obtain the peat dry mass. The water content was calculated by considering the peat dry mass and the peat wet mass measured before WEOM extraction.

\subsection{Structure of microbial communities - PLFAs}

Phospholipids-fatty acids (PLFAs) were extracted on freeze-dried peat samples using the Bligh and Dyer method (1959), modified for peat (Andersen et al., 2010). Peat samples (250 mg) were shaken during one hour in $15.6 \mathrm{ml}$ of a phosphate-buffer $(0.1 \mathrm{M} ; \mathrm{pH}$ 7): $\mathrm{CHCl}_{3}: \mathrm{MeOH}(0.9: 1: 2 \mathrm{v} / \mathrm{v} / \mathrm{v})$ solution. Then, the supernatant was transferred and $3.6 \mathrm{ml}$ of phosphate buffer and $4 \mathrm{ml}$ of chloroform were added. The mixture was then shaken for 1 minute before standing overnight for separation in the dark and then the bottom organic phase sampled and transferred. This $\mathrm{CHCl}_{3}$-lipid phase was then split into neutral, glyco- and phospholipids in a silicic acid column by eluting chloroform, acetone and methanol respectively. Phospholipids were then transesterified into fatty acid methyl esters (FAMEs) after a $20 \mathrm{~min}$ incubation time at $40{ }^{\circ} \mathrm{C}$ in a methanolic $\mathrm{KOH}(1 \mathrm{M})$ :toluene $(1: 1 \mathrm{v} / \mathrm{v})$ solution. The solution was neutralized with $3 \mathrm{ml}$ of acetic acid (1M) and FAMEs were extracted by adding a hexane: $\mathrm{CHCl}_{3}$ (4:1) solution. The hexane fraction is then passed through an $\mathrm{MgSO}_{4}$ column before evaporation to dryness under an $\mathrm{N}_{2}$ flux. 
FAMEs were analysed by means of GC-MS and quantified using a GC apparatus (Trace GC, Thermo Finnigan) equipped with a Supelco Equity 5-fused silica column (30 m length, 0.25 $\mathrm{mm}$ internal diameter, $0.25 \mu \mathrm{m}$ film thickness) coupled to a mass spectrometer (Quadrupole DSQ II, Thermo Finnigan). Helium was employed as the carrier gas at a constant flow rate. Methyl nonadecanoate $\left(\mathrm{C}_{19} \mathrm{O}_{2} \mathrm{Me}\right)$ was used as internal standard. Strict location of double bounds was realized by derivatization of FAMEs into picolinyl esters on representative samples (Wretensjö et al., 1990).

We used the PLFAs i15:0, a15:0, i16:0, i17:0 and a17:0 as markers of $\mathrm{G}+$ Bacteria

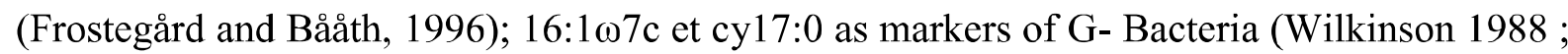
Zelles, 1999); 18:206,9 as marker of Fungi (Bardgett et al., 1996; Frostegård and Bååth, 1996; Zelles, 1999); 10Me16:0 and 10Me18:0 as markers of actinobacteria and sulfate-

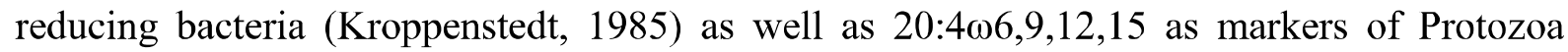
(Ringelberg et al., 1997). Other PLFAs detected in the samples were not specific to one particular functional group. Therefore, they were not used in the comparisons. PLFAs

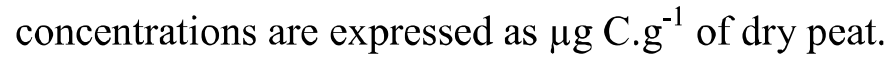

\subsection{Water-extractable organic matter analyses}

WEOM analyses were performed on the first part of each peat slice. The WEOM was divided into three aliquots for analyses of organic carbon (WEOC), total sugars and $\mathrm{SUVA}_{280}$, an index of the aromaticity of WEOM (Kalbitz et al., 2003). To calculate the WEOC, the dissolved organic carbon (DOC in $\mathrm{mg} \mathrm{l}^{-1}$ ) was first determined after acidification with $\mathrm{H}_{3} \mathrm{PO}_{4}$ $(\mathrm{pH}=4)$ and $\mathrm{N}_{2}$ purging. DOC was then measured with a Shimadzu SSM-5000A total carbon analyser. Finally, the mass of dissolved carbon was calculated and divided by the initial sample dry mass to obtain the WEOC expressed in mg. $\mathrm{g}^{-1}$ of dry peat. Total sugars were 
determined on the second aliquot following the phenol-sulfuric method with glucose as standard to allow the calculation of sugar content (Dubois et al., 1956). Total sugar contents were expressed in $\mathrm{mg}$ of carbon $\mathrm{g}^{-1}$ of dry peat, since we assumed that the weight ratio of carbon in sugars was that of glucose (2.5). For SUVA 280 , the third aliquot was adjusted to a $\mathrm{pH}$ ranging from 6 to 7 following the recommendation of Weishaar et al. (2003). UV absorbance was then measured at $280 \mathrm{~nm}$ using a UV spectrophotometer. Finally, SUVA 280 was calculated as absorbance divided by WEOC concentration (Hansson et al., 2010) and is expressed as $\mathrm{g}$ of dry peat per $\mathrm{mg} \mathrm{C}^{-1} \mathrm{~cm}^{-1}$.

\subsection{Extracellular enzymatic assays}

Enzymatic activities were measured on the second subsample of each slice. The activity of extracellular phenoloxidase was determined spectrophotometrically by using $10 \mathrm{mML}$-dopa (dihydroxyphenylalanine) solution as substrate (Pind et al., 1994). The activity of phenol oxidase (PO) was expressed in $\mu \mathrm{mol}$ of 2,3-dihydroindole-5,6-quinone-2-carboxylate (dicq) $\min ^{-1} \mathrm{~g}^{-1}$ of dry peat.

The activity of extracellular hydrolytic enzymes was measured by adding 4methylumbelliferyl-ß-D-glucoside for $\quad$-glucosidase (BG), L-leucine-7-amido-4methycoumarinhydrochloride for leucine aminopeptidase (LAP) and 4-MUF-phosphate for the activity of acidic phosphatase (AP) to about $1 \mathrm{~g}$ of fresh soil. After incubation $(1 \mathrm{~h}$ for BG, and LAP, and 45 min for AP), the fluorescence of the supernatant after centrifugation was measured on a microplate reader (BioTekSynergyMX) at 450-nm emission and 330-nm excitation wavelength. To quantify product release and account for quenching effects, a set of standards was prepared using methylumbelliferone (MUF) and 7-amino-4-methylcoumarin (MCU) mixed with peat extract (Freeman et al., 1995; Saiya-Cork et al., 2002). Hydrolytic 
enzyme activity was expressed as $\mu \mathrm{mol}$ of substrate (MUF) converted per minute and per gram of dry peat.

\subsection{Statistics}

To study the impact of air warming upon water content, PLFAs, WEOM features and extracellular enzymatic activities resulting from each depth, slices were pooled in order to obtain an overall response for the $25 \mathrm{~cm}$ peat column in each plot. All statistical analyses were performed using xlstat software (addinsoft $($ ). Data were tested for normality using the Kolmogorov-Smirnov test and for homogeneity of variance using the Levene test. Data were $\log 10$-transformed when non-normality and/or no homogeneity of the variance were found. Variations in air and peat temperatures were examined through Repeated Measures ANalysis Of VAriance (MANOVA) in order to test the singular impact and interactions of sites, air warming and time (i.e., months for air and peat temperatures). Following significant MANOVA tests $(p$-value $<0.05)$, significant differences were determined with Fisher's LSD tests. Variations in water content, PLFAs, WEOM features and extracellular enzymatic activities were analysed using ANOVA (i) to test the overall impact of air warming on these variables, (ii) to test the impact of air warming within the Bog and Fen sites and (iii) to investigate the impact of air warming on the initial differences distinguishing the Bog and Fen sites.

\section{Results}

\subsection{Air and Peat temperatures}

Continuous measurements of air temperature during the period from January to June 2011 in both control and OTC plots indicated significant effects related to the site type, warming 
treatment and time (Table 1). Minimum air temperature was significantly higher at the Fen site $\left(-3.8^{\circ} \mathrm{C}\right)$ than at the Bog site $\left(-4.2^{\circ} \mathrm{C}\right.$; Table 2$)$. Conversely, maximum air temperature was significantly higher at the Bog site $\left(19.3^{\circ} \mathrm{C}\right)$ than at the Fen site $\left(17.9^{\circ} \mathrm{C}\right)$. The single effect of air warming treatment also led to a rise in mean $\left(+0.8^{\circ} \mathrm{C}\right)$, minimum $\left(+0.4^{\circ} \mathrm{C}\right)$ and maximum $\left(+2.3^{\circ} \mathrm{C}\right)$ air temperatures (Table 2). More specifically, the experimental air warming treatment increased the mean $\left(+0.9^{\circ} \mathrm{C}\right)$, minimum $\left(+0.6^{\circ} \mathrm{C}\right)$ and maximum $\left(+2^{\circ} \mathrm{C}\right)$ air temperatures at the Bog site (Table 2). At the Fen site, OTCs were also associated with a rise in mean $\left(+0.7^{\circ} \mathrm{C}\right)$, minimum $\left(+0.3^{\circ} \mathrm{C}\right)$ and maximum $\left(+2.6^{\circ} \mathrm{C}\right)$ air temperatures (Table 2$)$.

Few specific effects of site or of the experimental warming were recorded on peat temperatures (Table 1). With OTC treatment, the minimum peat temperature decreased by $0.9^{\circ} \mathrm{C}$ (Table 2). Two significant differences were also observed due to the interaction between site and air warming: the minimum peat temperature was lower at the Bog-OTC $\left(3.3^{\circ} \mathrm{C}\right)$ than at the Bog-CTL plot $\left(5.0^{\circ} \mathrm{C}\right)($ Table 2$)$, and the mean peat temperature was higher at the Fen-OTC $\left(5.7^{\circ} \mathrm{C}\right)$ than at the Bog-OTC plot $\left(4.9^{\circ} \mathrm{C}\right)$. During the week before the sampling, the pattern was similar (Fig. 1), with no significant effect of experimental warming on peat temperature at the Fen site but a significant decrease in minimum peat temperature at the Bog site (from 11.1 to $10.4^{\circ} \mathrm{C}$ ). Additionally, experimental warming also induced a decrease of mean peat temperature in the Bog-OTC site $\left(11.3^{\circ} \mathrm{C}\right)$ as compared to the FenOTC $\left(12.9^{\circ} \mathrm{C}\right)$ site.

\subsection{Ground water level and peat water content changes}

From mid-May to late June 2011, the water level was systematically higher at the Fen than at the Bog site (+3 cm; Fig. 2) and it was strongly correlated with peat moisture from early May 2011 to late June 2011 (Fig. 3A). No significant relationship was found between peat 
moisture and air and peat temperature in the same time frame (Fig. 3B and 3C.). Instead, there was a positive correlation between air and peat temperature $(p<0.05)$ at both the Bog and Fen sites (Fig. 3D).

No overall effect of warming treatment was observed on peat water content (Table 3). More specifically, no significant changes were recorded at the Fen site, but water content was significantly higher in the Bog-OTC (94.5\%) site than in the corresponding control plots (93.3\%; Table 3). Water content in the control plots at the Bog and Fen sites were marginally significantly different $(p=0.07)$, but this trend disappeared under the effect of air warming.

\subsection{Water-extractable organic matter features and phospholipid fatty acids}

No impact of air warming treatment was recorded on WEOC, sugar content and SUVA 280 (Table 3). With respect to PLFA's, significant changes only occurred when comparing the effect of air warming treatment in Bog and Fen sites (Table 3), while no significant differences appeared between their control sites. In warmed plots, PLFAs from G-positive and G-negative bacteria became significantly higher at the Fen site compared to the Bog site (respectively 12.3 and $4.2 \mu \mathrm{g} \mathrm{C.g} \mathrm{g}^{-1}$ of dry peat in the Bog site and 47.3 and $18.8 \mu \mathrm{g} \mathrm{C}^{-\mathrm{g}^{-1}}$ of dry peat in the Fen site - Table 3). Control plots in the Fen had also higher Protozoan contents as compared to control plots in the Bog, but this difference did not persist under warming treatment.

\subsection{Enzymatic activities}

There was no overall effect of warming treatment on enzymatic activity (Table 3). Nevertheless, at the Bog site, warming treatment significantly enhanced the AP activity. In 
warmed plots, the activity of LAP and AP were significantly higher at the Bog site as compared to the Fen site (respectively. 5.4 and $1.4 \mu \mathrm{mol} \mathrm{MUF} \min ^{-1} \mathrm{~g}^{-1}$ at the Bog-site and whereas 4.7 and $1.4 \mu \mathrm{mol}$ MUF $\min ^{-1} \mathrm{~g}^{-1}$ at the Fen site).

\section{Discussion}

\subsection{Experimental air warming enhances the discrepancy of peat temperatures between} Bog and Fen sites

From January to June 2011 , the OTCs enhanced mean air temperature up to $0.9^{\circ} \mathrm{C}$ and $0.7^{\circ} \mathrm{C}$ in the Bog and the Fen sites, respectively. Such a temperature rise is in accordance with other in situ warming experiments with OTCs (Sullivan et al., 2008; Dorrepaal et al., 2009; Weedon et al., 2012). The increase of air temperature was associated with a decrease of minimum peat temperature under the impact of warming, especially at the Bog site (Tables 1 and 2). At the Bog site, the increase of air temperature was also associated with an increase of peat water content (Table 3). This result is surprising since most studies on experimental warming reported a decrease or no effect on peat moisture (Hollister et al., 2006; Dorrepaal et al., 2009; Bokhorst et al., 2011; Delarue et al., 2011b; Jassey et al., 2013). The question is therefore to know whether this effect was due to an experimental artefact or if it results from a thermodynamic constraint. It has already been demonstrated that OTCs can stop wind blowing, thus reducing evaporation (de Boeck et al., 2012). As no relationship was found between wind speed and peat moisture (at $5 \mathrm{~cm}$ depth) in the control plots (data not shown), we would assume that no significant reduction of evaporation by OTCs occured at $5 \mathrm{~cm}$ depth. However, we cannot rule out the effect of wind at the surface of the Sphagnum carpet. In both sites, peat moisture was mainly controlled by ground water level rather than by air 
temperature (Fig. 3A, B and C). Therefore, such a rise in peat moisture at the Bog site may result from an interaction between air temperature and ground water level owing to capillary strength. It was demonstrated that water capillary flow is the main mass flux within peat (Price et al., 2009). If the capillary flow is not strong enough to compensate for the evaporation rate, mosses start to dry out. Conversely, if the capillary flow compensates for the evaporation rate (Yazaki et al., 2006), then the vapour diffusion through evaporation can cool the upper peat layer (Carleton and Dunham, 2003). In addition, this can lead to the condensation of vapour in the upper peat layer, which triggers a slight increase in peat moisture (Price et al., 2009). This mechanism can partially explain the observed increase in peat water content and the decrease in minimum peat temperature at the Bog site since this site was not associated with a reduction of the average peat temperature. At the Fen site, no temperature changes were recorded. Due to the different effect of experimental warming in the two sites, one can conclude to a thermal discrepancy, as indicated by the lower peat temperature at the Bog-OTC as compared to the Fen-OTC site (Table 2). Such a discrepancy was also measured the week before sampling (Fig. 1) and indeed, this thermal discrepancy was associated with the disappearance of water content discrepancy between the warmed and fen sites (Table 3)

Overall, this discrepancy indicates that a slightly higher water level (about $3 \mathrm{~cm}$; Fig. 2) may prevent any effect of experimental warming on both peat temperature and moisture, suggesting that a potential thermodynamic threshold occurs as a function of groundwater level. In our work, data on the capillary fringe are lacking. Albeit our measurements of water content (Table 3) can hardly be considered as an accurate variable to characterize capillary fringe, our results emphasize the necessity of a high-resolution description of peat moisture when assessing impact of warming on peatlands. 


\subsection{Air warming can lead to changes of microbial structure and activities in opposite directions.}

At the Bog site, air warming treatment led to higher AP enzymatic activity. This enzyme is produced by both soil microorganisms and plants and is involved in the mineralization of phosphate from phospholipids (Turner et al., 2002; Toor et al., 2003). AP changes underpin a higher breakdown of organically bound phosphate at the Bog site in the course of air warming. A particular attention must be paid to the impact of roots which are considered as key controlling factors of AP activity (Robroek et al., 2013). Indeed, it was demonstrated that air warming favoured vascular plant abundance rather than Sphagnum mosses (Jassey et al. 2013). Roots are lacking in Sphagnum species, and therefore it can be expected that the root activity increase of vascular plants triggers AP activity. Jassey and coworkers (2013) also indicated that this vegetation shift was associated with a decrease of Sphagnum-polyphenols, a strong microbial breakdown inhibitor, stimulating, in turn, the bacterial and microbial enzymatic activities (Fenner and Freeman 2011). Here, the lack of changes upon POA, BG and LAP do not give evidences of such a phenomenon.

Air warming also raised discrepancies between Bog and Fen sites when comparing first the control plots and then, the warmed plots of both sites. Thus, the increase of enzymatic activities at the warmed Bog site could be linked to higher temperature fluctuations in both the air and the soil, which would have triggered their kinetics (Davidson and Janssens, 2006). Additionally, PLFAs indicated that bacterial biomass increased at the warmed Fen site (Table 3). This suggests that air warming can alter the microbial structure and enzyme hydrolytic activities in opposite directions at the scale of the Bog and Fen sites. Thus, air warming might induce the emergence of differential peat carbon dynamics in Bog and Fen sites. Following the scheme of the soil carbon cycle of Schimel and Weintraub (2003), one could hypothesize 
that carbon uptake by microbial cell biomass was favoured at the warmed Fen site, whereas it was hydrolytic enzyme production that was favoured at the warmed Bog site. However, it was also demonstrated in a snow removal experiment that differential timing of peat defrosting or snow melting can induced delays in microbial community response (Robroek et al. 2013). Thus, predominance of fungi upon bacterial biomass was used as an indicator of the winter state of the microbial community (Robroek et al. 2013). At the warmed Fen site, the relative shift of microbial structure to bacterial biomass could indicate that microbial community was in an advanced seasonal stage as compared to the Bog site. Moreover, an increase of enzymatic activities could also take place as a physiological adjustment to survive cold temperature (Beales, 2004). In any case, this advocates a more careful observation of the spring period after snow melting.

Peat moisture was defined as the main controlling factor differentiating $\mathrm{OM}$ decomposition in the Bog and Fen sites (Delarue et al. 2011a). A change in moisture condition should therefore induce a change of peat carbon cycle. Here, we have seen that water content, which was marginally significantly different between Bog and Fen control plots was not any more different in warmed plots. Such a change was confirmed by PLFA's from protozoan and indeed, it is known that testate amoebae are positively correlated to peat moisture and watertable depths (Woodland, 1998). Peat carbon cycle can be roughly divided into 4 components: soil organic carbon; dissolved organic carbon (WEOC in this study), microbial cell biomass and exoenzymes (Schimel and Weintraub, 2003). WEOC is an intermediate product between solid and gas phases in the course of decomposition (Schimel and Weintraub, 2003) and is considered as an indicator of the portion of dissolved OM which is the most active and mobile fraction within the OM (Akagi and Zsolnay, 2008; Zaccone et al., 2009). No significant change between control and warmed plots or between warmed Bog and Fen sites were recorded (Table 3). Moreover, WEOC mainly depended on sugar content which is known to 
be ubiquitous, occurring within both peat and microorganisms (results not shown). WEOC and sugar content were not enough discriminant to conclude anything about OM decomposition under the impact of OTCs in Bog and Fen sites. Additionally, since no change occurred upon $\mathrm{SUVA}_{280}$, which should reflect the decomposition of recalcitrant aromatic moieties, our results suggest that air warming did impact neither recalcitrant nor labile OM pools in this study.

Through various approaches, we highlighted the limitation of the use of single indicators of OM decomposition such as WEOM features, PLFAs or enzymatic activities, which are classically used in such studies, since this can lead to fallacious conclusions. In particular, our results emphasise a change in microbial structure and activities as a consequence of complex interactions between groundwater level and air warming. Future investigations should aim at characterizing the seasonal pattern of these interactions, taking also into consideration soil microtopographic features, since this will greatly affect the impact of global warming on peat decomposition.

\section{Acknowledgments}

This work was funded as part of the PEATWARM initiative through an ANR (French National Agency for Research) grant (ANR-07-VUL-010). This paper is a contribution to the research conducted in the Labex VOLTAIRE (ANR-10-LABX-100-01). The authors are also indebted to the Regional Scientific Council of Natural Heritage of the Franche-Comté Region for access to Le Forbonnet site. They are grateful to CETRAHE laboratory for analytical assistance. They would like to thank N. Pothier and L. Catherine for logistical assistance and E. Rowley-Jolivet for revision of the English version. 


\section{References}

Aerts, R., Cornelissen, J.H.C., Dorrepaal, E., 2006. Plant performance in a warmer world: General responses of plants from cold, northern biomes and the importance of winter and spring events. Plant Ecology 182(1-2), 65-77.

Akagi, J., Zsolnay, A., 2008. Effects of long-term de-vegetation on the quantity and quality of water extractable organic matter (WEOM): Biogeochemical implications. Chemosphere $72(10), 1462-1466$.

Andersen, R., Grasset, L., Rochefort, L., Thormann, MN, Francez, A-J. 2010. Changes in microbial community structure and function following Sphagnum peatland restoration. Soil Biology \& Biochemistry 42, 291-301.

Aronson, E.L., McNulty, S.G., 2009. Appropriate experimental ecosystem warming methods by ecosystem, objective, and practicality. Agricultural and Forest Meteorology 149(11), 1791 1799.

Bardgett, R.D., Hobbs, P.J., Frostegård, Å. 1996. Changes in soil fungal:bacterial biomass ratios following reductions in the intensity of management of an upland grassland. Biol Fertil Soils 22, 261-264.

Beales, N. 2004. Adaptation of microorganisms to cold temperatures, weak acid preservatives, low $\mathrm{pH}$, and osmotic stress: a review. Comprehensive Reviews in Food science and Food safety 3, 1-20.

Bligh, E.G., Dyer, W.G. 1959. A rapid method of total lipid extraction and purification. Can J Biochem Physiol 37, 911-917.

Bokhorst, S., Huiskes, A., Aerts, R., Convey, P., Cooper, E.J., Dalen, L., Erschbamer, B., Gudmundsson, J., Hofgaard, A., Hollister, R.D., Johnstone, J., Jonsdottir, I.S., Lebouvier, M., 
Van De Vijver, B., Wahren, C.H., Dorrepaal, E., 2013. Variable temperature effects of Open

Top Chambers at polar and alpine sites explained by irradiance and snow depth. Global Change Biology 19(1), 64-74.

Bokhorst, S., Huiskes, A., Convey, P., Sinclair, B.J., Lebouvier, M., Van de Vijver, B., Wall, D.H., 2011. Microclimate impacts of passive warming methods in Antarctica: implications for climate change studies. Polar Biology 34(10), 1421-1435.

Bragazza, L., Parisod, J., Buttler, A., Bardgett, R.D., 2013. Biogeochemical plant-soil microbe feedback in response to climate warming in peatlands. Nature Climate Change 3(3), $273-277$.

Breeuwer, A., Heijmans, M., Gleichman, M., Robroek, B.J.M., Berendse, F., 2009. Response of Sphagnum species mixtures to increased temperature and nitrogen availability. Plant Ecology 204(1), 97-111.

Carleton, T.J., Dunham, K.M.M., 2003. Distillation in a boreal mossy forest floor. Canadian Journal of Forest Research-Revue Canadienne De Recherche Forestiere 33(4), 663-671.

Charman, D.J., Beilman, D.W., Blaauw, M., Booth, R.K., Brewer, S., Chambers, F.M., Christen, J.A., Gallego-Sala, A., Harrison, S.P., Hughes, P.D.M., Jackson, S.T., Korhola, A., Mauquoy, D., Mitchell, F.J.G., Prentice, I.C., van der Linden, M., De Vleeschouwer, F., Yu, Z.C., Alm, J., Bauer, I.E., Corish, Y.M.C., Garneau, M., Hohl, V., Huang, Y., Karofeld, E., Le Roux, G., Loisel, J., Moschen, R., Nichols, J.E., Nieminen, T.M., MacDonald, G.M., Phadtare, N.R., Rausch, N., Sillasoo, U., Swindles, G.T., Tuittila, E.S., Ukonmaanaho, L., Valiranta, M., van Bellen, S., van Geel, B., Vitt, D.H., Zhao, Y., 2013. Climate-related changes in peatland carbon accumulation during the last millennium. Biogeosciences 10(2), 929-944. 
Dabros, A., Fyles, J.W., 2010. Effects of open-top chambers and substrate type on biogeochemical processes at disturbed boreal forest sites in northwestern Quebec. Plant and Soil 327(1-2), 465-479.

Davidson, E.A., Janssens, I.A., 2006. Temperature sensitivity of soil carbon decomposition and feedbacks to climate change. Nature 440(7081), 165-173.

De Boeck, H.J., De Groote, T., Nijs, I., 2012. Leaf temperatures in glasshouses and open-top chambers. New Phytologist 194(4), 1155-1164.

Delarue, F., Laggoun-Defarge, F., Disnar, J.R., Lottier, N., Gogo, S., 2011a. Organic matter sources and decay assessment in a Sphagnum-dominated peatland (Le Forbonnet, Jura Mountains, France): impact of moisture conditions. Biogeochemistry 106(1), 39-52.

Delarue, F., Laggoun-Defarge, F., Buttler, A., Gogo, S., Jassey, V.E.J., Disnar, J.R., 2011 b. Effects of short-term ecosystem experimental warming on water-extractable organic matter in an ombrotrophic Sphagnum peatland (Le Forbonnet, France). Organic Geochemistry 42(9), $1016-1024$

Dorrepaal, E., Toet, S., van Logtestijn, R.S.P., Swart, E., van de Weg, M.J., Callaghan, T.V., Aerts, R., 2009. Carbon respiration from subsurface peat accelerated by climate warming in the subarctic. Nature 460(7255), 616-U679.

Dubois, M., Gilles, K.A., Hamilton, J.K., Rebers, P.A., Smith, F., 1956. Colorimetric method for determination of sugars and related substances. Analytical Chemistry 28(3), 350-356.

Fenner, N., Freeman, C., 2011. Drought-induced carbon loss in peatlands. Nature Geoscience 4(12), 895-900.

Freeman, C., Liska, G., Ostle, N.J., Jones, S.E., Lock, M.A., 1995. the use of fluorogenic substrates for measuring enzyme-activity in peatlands. Plant and Soil 175(1), 147-152. 
Freeman, C., Ostle, N., Kang, H., 2001. An enzymic 'latch' on a global carbon store - A shortage of oxygen locks up carbon in peatlands by restraining a single enzyme. Nature 409(6817), 149-149.

Freeman, C., Ostle, N.J., Fenner, N., Kang, H., 2004. A regulatory role for phenol oxidase during decomposition in peatlands. Soil Biology \& Biochemistry 36(10), 1663-1667.

Friedlingstein, P., Cox, P., Betts, R., Bopp, L., Von Bloh, W., Brovkin, V., Cadule, P., Doney, S., Eby, M., Fung, I., Bala, G., John, J., Jones, C., Joos, F., Kato, T., Kawamiya, M., Knorr, W., Lindsay, K., Matthews, H.D., Raddatz, T., Rayner, P., Reick, C., Roeckner, E., Schnitzler, K.G., Schnur, R., Strassmann, K., Weaver, A.J., Yoshikawa, C., Zeng, N., 2006. Climate-carbon cycle feedback analysis: Results from the (CMIP)-M-4 model intercomparison. Journal of Climate 19(14), 3337-3353.

Frostegård, Å., Bååth, E. 1996. The use of phospholipid fatty acid analysis to estimate bacterial and fungal biomass in soil. Biol Fert Soils 22, 59-65.

Gorham, E., 1991. Northern peatlands : role in the carbon-cycle and probable responses to climatic warming. Ecological Applications 1(2), 182-195.

Hansson, K., Kleja, D.B., Kalbitz, K., Larsson, H., 2010. Amounts of carbon mineralised and leached as DOC during decomposition of Norway spruce needles and fine roots. Soil Biology \& Biochemistry 42(2), 178-185.

Hollister, R.D., Webber, P.J., Nelson, F.E., Tweedie, C.E., 2006. Soil thaw and temperature response to air warming varies by plant community: Results from an open-top gamber experiment in northern Alaska. Arctic Antarctic and Alpine Research 38(2), 206-215.

I.P.C.C., (Intergovernmental Panel on Climate Change) 2007. Climate Change 2007: The Physical Science Basis. Cambridge University Press

Jassey, V.E.J., Chiapusio, G., Binet, P., Buttler, A., Laggoun-Defarge, F., Delarue, F., Bernard, N., Mitchell, E.A.D., Toussaint, M.L., Francez, A.J., Gilbert, D., 2013. Above- and 
belowground linkages in Sphagnum peatland: climate warming affects plant-microbial interactions. Global Change Biology 19(3), 811-823.

Jassey, V.E.J., Chiapusio, G., Gilbert, D., Buttler, A., Toussaint, M.L., Binet, P., 2011. Experimental climate effect on seasonal variability of polyphenol/phenoloxidase interplay along a narrow fen-bog ecological gradient in Sphagnum fallax. Global Change Biology 17(9), 2945-2957.

Kalbitz, K., Schwesig, D., Schmerwitz, J., Kaiser, K., Haumaier, L., Glaser, B., Ellerbrock, R., Leinweber, P., 2003. Changes in properties of soil-derived dissolved organic matter induced by biodegradation. Soil Biology \& Biochemistry 35(8), 1129-1142.

Kroppenstedt, R.M. 1985. Fatty acid and Menaquinone analysis of actinomycetes and related organisms, in: Goodfellow, M., Minnikin, D.E. (Eds.) Chemical Methods in Bacterial Systematics, Academic Press, London, pp. 173-199.

Loisel, J., Yu, Z.C., 2013. Recent acceleration of carbon accumulation in a boreal peatland, south central Alaska. Journal of Geophysical Research-Biogeosciences 118(1), 41-53.

Marion, G.M., Henry, G.H.R., Freckman, D.W., Johnstone, J., Jones, G., Jones, M.H., Levesque, E., Molau, U., Molgaard, P., Parsons, A.N., Svoboda, J., Virginia, R.A., 1997. Open-top designs for manipulating field temperature in high-latitude ecosystems. Global Change Biology 3, 20-32.

McLatchey, G.P., Reddy, K.R., 1998. Regulation of organic matter decomposition and nutrient release in a wetland soil. Journal of Environmental Quality 27(5), 1268-1274.

McNeil, P., Waddington, J.M., 2003. Moisture controls on Sphagnum growth and CO2 exchange on a cutover bog. Journal of Applied Ecology 40(2), 354-367.

Otto, A., Otto, F.E.L., Boucher, O., Church, J., Hegerl, G., Forster, P.M., Gillett, N.P., Gregory, J., Johnson, G.C., Knutti, R., Lewis, N., Lohmann, U., Marotzke, J., Myhre, G., 
Shindell, D., Stevens, B., Allen, M.R., 2013. Energy budget constraints on climate response. Nature Geoscience 6(6), 415-416.

Pind, A., Freeman, C., Lock, M.A., 1994. Enzymatic degradation of phenolic materials in peatlands - measurement of phenol oxidase activity. Plant and Soil 159(2), 227-231.

Price, J.S., Edwards, T.W.D., Yi, Y., Whittington, P.N., 2009. Physical and isotopic characterization of evaporation from Sphagnum moss. Journal of Hydrology 369(1-2), $175-$ 182.

Ringelberg, D.B., Stair, J.O., Almeida, J., Norby, R.J., O’Neil, E.G., White, D.C. (1997) Consequences of rising atmospheric carbon dioxide levels for the belowground microbiota associated with white oak. J Env Qual 26, 495-503.

Robroek, B.J.M, Heijboer, A., Jassey, V.E.J., Hefting, M.M.T, Rouwenhorst, G., Buttler, A., Bragazza, L. (2013) Snow cover manipulation effects on microbial community structure and soil chemistry in a mountain bog. Plant and Soil 369, 151-164.

Saiya-Cork, K.R., Sinsabaugh, R.L., Zak, D.R., 2002. The effects of long term nitrogen deposition on extracellular enzyme activity in an Acer saccharum forest soil. Soil Biology \& Biochemistry 34(9), 1309-1315.

Schimel, J.P., Weintraub, M.N., 2003. The implications of exoenzyme activity on microbial carbon and nitrogen limitation in soil: a theoretical model. Soil Biology \& Biochemistry 35(4), 549-563.

Sullivan, P.F., Arens, S.J.T., Chimner, R.A., Welker, J.M., 2008. Temperature and microtopography interact to control carbon cycling in a high arctic fen. Ecosystems 11(1), 61 76.

Toor, G.S., Condron, L.M., Di, H.J., Cameron, K.C., Cade-Menun, B.J., 2003. Characterization of organic phosphorus in leachate from a grassland soil. Soil Biology \& Biochemistry 35(10), 1317-1323. 
Turner, B.L., McKelvie, I.D., Haygarth, P.M., 2002. Characterisation of water-extractable soil organic phosphorus by phosphatase hydrolysis. Soil Biology \& Biochemistry 34(1), 27-35.

Van breemen, N., 1995. How sphagnum bogs down other plants. Trends in Ecology \& Evolution 10(7), 270-275.

Weedon, J.T., Kowalchuk, G.A., Aerts, R., van Hal, J., van Logtestijn, R., Tas, N., Roling, W.F.M., van Bodegom, P.M., 2012. Summer warming accelerates sub-arctic peatland nitrogen cycling without changing enzyme pools or microbial community structure. Global Change Biology 18(1), 138-150.

Weishaar, J.L., Aiken, G.R., Bergamaschi, B.A., Fram, M.S., Fujii, R., Mopper, K., 2003. Evaluation of specific ultraviolet absorbance as an indicator of the chemical composition and reactivity of dissolved organic carbon. Environmental Science \& Technology 37(20), 47024708.

Wilkinson, S.C. 1988. Gram-negative bacteria, in: Ratledge, C., Wilkinson, S.C. (Eds) Microbial lipids, vol 1. Academic, London, pp 299-488.

Woodland, W.A., Charman, D.J., Sims, P.C. 1998. Quantitative estimates of water tables and soil moisture in Holocene peatlands from testate amoebae. The Holocene 8, 261-273.

Wretensjö, I., Svensson, L., Christie, W.W. 1990. Gas chromatographic-mass spectrometric identification of the fatty acids in borage oil using the picolinyl ester derivatives. J Chromatogr 521, 89-97.

Yazaki, T., Urano, S., Yabe, K., 2006. Water balance and water movement in unsaturated zones of Sphagnum hummocks in Fuhrengawa Mire, Hokkaido, Japan. Journal of Hydrology $319(1-4), 312-327$.

Zaccone, C., D'Orazio, V., Shotyk, W., Miano, T.M., 2009. Chemical and spectroscopic investigation of porewater and aqueous extracts of corresponding peat samples throughout a bog core (Jura Mountains, Switzerland). Journal of Soils and Sediments 9(5), 443-456. 
Zelles, L. 1999. Fatty acid patterns of phospholipids and lipopolysaccharides in the characterisation of microbial communities in soil: a review. Biol Fert Soils 29, 111-129. 


\section{Figure captions}

Fig. 1: Effect of experimental warming on mean, minimum and maximum peat temperatures at both Bog and Fen sites during the week before sampling. Each value corresponds to the weekly mean, minimum and maximum peat temperatures. Error bars are indicative of standard error between replicates $(n=3)$. Significant differences are indicated by different letters.

Fig. 2: Ground water level (below the Sphagnum capitulum) measured at both Bog and Fen sites from mid-May to late June.

Fig. 3: Relationships between ground water level and peat moisture (A), peat moisture and air mean temperature (B), peat moisture and peat mean temperature (C) and air and peat mean temperatures (D) at both Bog and Fen sites. Measurements were performed from mid-May 2011 to late June 2011. A significant correlation coefficient is indicated by an asterisk ( $p<$ 0.05). Each value corresponds to a daily mean value. 
Table 1: Results of a Repeated Measures ANOVA's to test the overall and interaction effects of time, site and experimental warming on air and peat temperatures. Mean, minimum and maximum monthly temperatures from January 2011 to June 2011 were used as repeated measures. Significant differences are indicated by a $p$-value below 0.05 .

\section{Air temperatures}

\begin{tabular}{lcccccccccc} 
& & \multicolumn{2}{c}{ Mean } & & \multicolumn{2}{c}{ Minimum } & & \multicolumn{2}{c}{ Maximum } \\
Effect & $d f$ & $\boldsymbol{F}$ & $\boldsymbol{p}$ & & $\boldsymbol{F}$ & $\boldsymbol{p}$ & & $\boldsymbol{F}$ & $\boldsymbol{p}$ \\
\hline Site & 1 & 2.44 & 0.16 & & 11.65 & $<\mathbf{0 . 0 5}$ & & 5.77 & $<\mathbf{0 . 0 5}$ \\
Treatment & 1 & 42.94 & $<\mathbf{0 . 0 5}$ & & 15.71 & $<\mathbf{0 . 0 5}$ & & 16.02 & $<\mathbf{0 . 0 5}$ \\
Time & 5 & 25639.89 & $<\mathbf{0 . 0 5}$ & & 4220.60 & $<\mathbf{0 . 0 5}$ & & 3492.06 & $<\mathbf{0 . 0 5}$ \\
Site $\times$ Treat. & 1 & 0.36 & 0.56 & & 1.78 & 0.22 & & 0.23 & 0.64 \\
Site $\times$ Time & 5 & 4.23 & $<\mathbf{0 . 0 5}$ & & 2.74 & $<\mathbf{0 . 0 5}$ & & 5.09 & $<\mathbf{0 . 0 5}$ \\
Treat. $\times$ Time & 5 & 21.16 & $<\mathbf{0 . 0 5}$ & & 1.26 & 0.30 & & 15.20 & $<\mathbf{0 . 0 5}$ \\
Site $\times$ Treat. $\times$ Time & 5 & 0.29 & 0.92 & & 0.38 & 0.86 & & 0.19 & 0.97 \\
\hline
\end{tabular}

\section{Peat temperatures}

\begin{tabular}{|c|c|c|c|c|c|c|c|}
\hline \multirow[b]{2}{*}{ Effect } & \multirow[b]{2}{*}{$d f$} & \multicolumn{2}{|c|}{ Mean } & \multicolumn{2}{|c|}{ Minimum } & \multicolumn{2}{|c|}{ Maximum } \\
\hline & & $F$ & $p$ & $F$ & $p$ & $F$ & $p$ \\
\hline Site & 1 & 2.81 & 0.13 & 0.01 & 0.93 & 1.77 & 0.22 \\
\hline Treatment & 1 & 0.01 & 0.91 & 6.69 & $<0.05$ & 2.01 & 0.19 \\
\hline Time & 5 & 1389.12 & $<0.05$ & 969.23 & $<0.05$ & 391.76 & $<0.05$ \\
\hline Site $\times$ Treat & 1 & 3.28 & 0.11 & 6.90 & $<0.05$ & 0.01 & 0.92 \\
\hline Site $\times$ Time & 5 & 1.37 & 0.26 & 1.01 & 0.42 & 1.14 & 0.35 \\
\hline Treat. $\times$ Time & 5 & 1.03 & 0.41 & 6.08 & $<0.05$ & 2.01 & 0.10 \\
\hline Site $\times$ Treat. $\times$ Time & 5 & 0.32 & 0.90 & 3.63 & $<0.05$ & 0.28 & 0.92 \\
\hline
\end{tabular}


Table 2: Air and peat temperatures $\left({ }^{\circ} \mathrm{C}\right)$ according to sites, warming treatment and their interactions Mean, minimum and maximum temperatures were calculated according to monthly temperatures from January 2011 to June 2011. Significant differences are indicated by a $p$-value below 0.05 .

Air temperatures

Mean Min. Max.

Site $(n=6)$

Bog

Fen

p-value

(1)

(2)

Mean

Min.

Max.

temperature temperature temperature

Treatment $(n=6)$

Control

5.7

6.5

Warmed

p-value

$<0.05$

$-3.8$

$<0.05$

Min.

Max.

temperature temperature temperature

$\times$ Treatment $(n=3)$ 
Table 3: Effect of warming treatment on PLFAs (G+bacteria, G-bacteria, Fungi, Actinobacteria and Protozoan in $\mu \mathrm{g} \mathrm{C.g}{ }^{-1}$ of dry peat), water content, WEOM features (Waterextractable organic carbon in $\mathrm{mg}^{-\mathrm{g}^{-1}}$ of dry peat, sugar content in $\mathrm{mg}^{-\mathrm{g}^{-1}}$ of dry peat and SUVA $_{280}$ in $\mathrm{g}$ of dry peat per $\mathrm{mg} \mathrm{C}^{-1} \mathrm{~cm}^{-1}$ ) and extracellular enzymatic activities (phenoloxidase-PO in $\mu \mathrm{mol}$ of dicq min-1 $\mathrm{g}^{-1}$ of dry peat., ß-glucosidase-BG, leucine aminopeptidase-LA and acidic phosphatase-AP in $\mu \mathrm{mol}$ of substrate). The impact of warming was tested with Bog-CTL vs. Bog-OTC, Fen-CTL vs. Fen-OTC, Bog-CTL vs. Fen CTL, BogOTC vs. Fen-OTC and CTL vs. OTC. Significant differences are indicated with bold characters.

\begin{tabular}{lccccc}
$\begin{array}{l}\text { PLFAs } \\
\text { (Average value) }\end{array}$ & G+ bacteria & G- bacteria & Fungi & Actinobacteria & Protozoan \\
\hline CTL & 19.5 & 7.3 & 2.7 & 6.7 & 5.7 \\
OTC & 29.8 & 11.5 & 6.1 & 9.5 & 5.9 \\
Bog-CTL & 14.1 & 5.7 & 1.4 & 3.9 & 2.3 \\
Bog-OTC & 12.3 & 4.2 & 6.0 & 7.2 & 4.3 \\
Fen-CTL & 25.0 & 8.8 & 4.1 & 9.5 & 9.0 \\
Fen-OTC & 47.3 & 18.8 & 6.1 & 11.7 & 7.5 \\
& & & & & \\
$p$-value & G+ bacteria & G- bacteria & Fungi & Actinobacteria & Protozoan \\
\hline CTL vs. OTC & 0.38 & 0.37 & 0.28 & 0.41 & 0.91 \\
Bog-CTL vs. Bog-OTC & 0.89 & 0.74 & 0.43 & 0.48 & 0.49 \\
Fen-CTL $v s$. Fen-OTC & 0.14 & 0.14 & 0.59 & 0.65 & 0.18 \\
Bog-CTL $v s$. Fen CTL & 0.38 & 0.51 & 0.11 & 0.23 & $\mathbf{0 . 0 4}$ \\
Bog-OTC vs. Fen-OTC & $\mathbf{0 . 0 5}$ & $\mathbf{0 . 0 5}$ & 0.99 & 0.40 & 0.15
\end{tabular}

\section{Water content and}

WEOM features

(Average value)

CTL

Water content WEOC Suga

OTC

Bog-CTL

Bog-OTC

Fen-CTL

93.8

94.2

93.3

94.5

94.3

93.9

content

Fen-OTC

2.9

1.2

1.1

1.2

1.1

1.1

1.2 SUVA $_{280}$

0.066

$\begin{array}{lll}2.8 & 1.1 & 0.073\end{array}$

2.9

0.059

2.6

0.062

\begin{tabular}{lcccc}
$p$-value & Water content & WEOC & $\begin{array}{c}\text { Sugar } \\
\text { content }\end{array}$ & SUVA $_{280}$ \\
\hline CTL vs. OTC & 0.27 & 0.38 & 0.81 & 0.84 \\
Bog-CTL vs. Bog-OTC & $\mathbf{0 . 0 4}$ & 0.89 & 0.44 & 0.98 \\
Fen-CTL vs. Fen-OTC & 0.40 & 0.32 & 0.92 & 0.62 \\
Bog-CTL vs. Fen CTL & 0.07 & 0.84 & 0.77 & 0.23 \\
Bog-OTC vs. Fen-OTC & 0.21 & 0.55 & 0.77 & 0.09
\end{tabular}

\section{Extracellular}




\begin{tabular}{lcccc} 
CTL & 0.0041 & 0.7 & 5.2 & 1.3 \\
OTC & 0.0034 & 0.7 & 5.0 & 1.2 \\
Bog-CTL & 0.0042 & 0.7 & 4.8 & 1.3 \\
Bog-OTC & 0.0044 & 0.8 & 5.4 & 1.4 \\
Fen-CTL & 0.0040 & 0.8 & 5.6 & 1.3 \\
Fen-OTC & 0.0024 & 0.6 & 4.7 & 1.0 \\
& & & & \\
p-value & PO & BG & LAP & AP \\
\hline CTL $v s$. OTC & 0.45 & 0.84 & 0.72 & 0.60 \\
Bog-CTL $v s$. Bog-OTC & 0.91 & 0.33 & 0.32 & $\mathbf{0 . 0 3}$ \\
Fen-CTL $v$ s. Fen-OTC & 0.13 & 0.14 & 0.10 & 0.13 \\
Bog-CTL $v s$. Fen CTL & 0.75 & 0.34 & 0.29 & 0.84 \\
Bog-OTC $v s$. Fen-OTC & 0.26 & 0.08 & $\mathbf{0 . 0 3}$ & $\mathbf{0 . 0 1}$
\end{tabular}




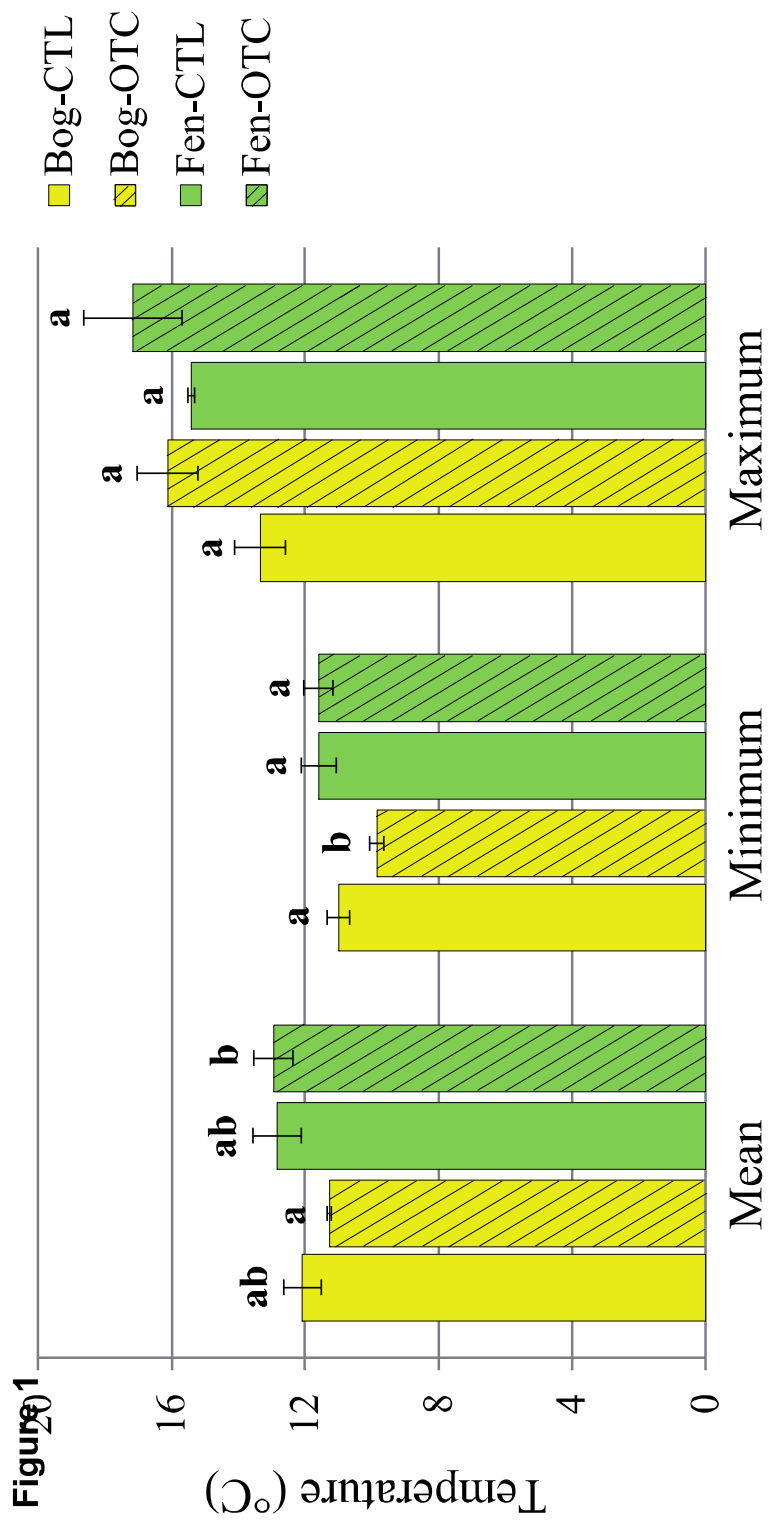




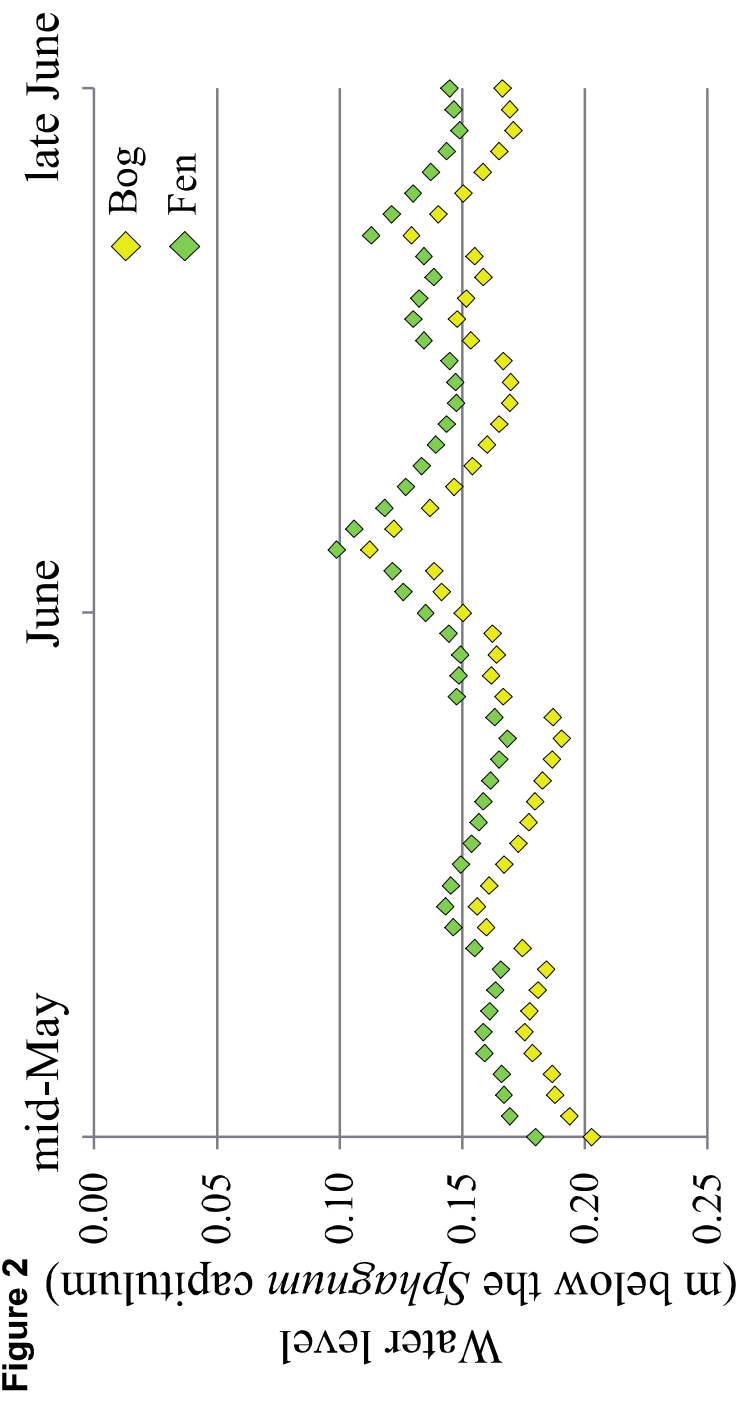


